\title{
Recent advances in understanding and managing urolithiasis
}

\section{[version 1; peer review: 3 approved]}

\author{
Walter L. Strohmaier ${ }^{1,2}$ \\ ${ }^{1}$ Department of Urology and Paediatric Urology, Regiomed-Kliniken, Coburg, Germany \\ ${ }^{2}$ Academic Hospital of the University of Split, Split, Croatia
}

V1 First published: 08 Nov 2016, 5(F1000 Faculty Rev):2651

https://doi.org/10.12688/f1000research.9570.1

Latest published: 08 Nov 2016, 5(F1000 Faculty Rev):2651

https://doi.org/10.12688/f1000research.9570.1
Open Peer Review

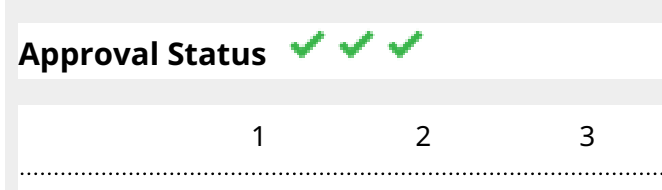

version 1

08 Nov 2016

Faculty Reviews are review articles written by the prestigious Members of Faculty Opinions. The articles are commissioned and peer reviewed before publication to ensure that the final, published version is comprehensive and accessible. The reviewers who approved the final version are listed with their names and affiliations.

1. Chanderdeep Tandon, Amity University,

Noida, India

2. Amy Krambeck, Indiana University, Indianapolis, USA

3. Hans-Goran Tiselius, Department of Clinical Science Intervention and Technology, Stockholm, Sweden

Any comments on the article can be found at the end of the article. 
Corresponding author: Walter L. Strohmaier (walter.strohmaier@klinikum-coburg.de)

Competing interests: The author is a consultant of Bionorica SE, Neumarkt/Oberpfalz, Germany.

Grant information: The author(s) declared that no grants were involved in supporting this work.

Copyright: $\odot 2016$ Strohmaier WL. This is an open access article distributed under the terms of the Creative Commons Attribution License, which permits unrestricted use, distribution, and reproduction in any medium, provided the original work is properly cited.

How to cite this article: Strohmaier WL. Recent advances in understanding and managing urolithiasis [version 1; peer review: 3 approved] F1000Research 2016, 5(F1000 Faculty Rev):2651 https://doi.org/10.12688/f1000research.9570.1

First published: 08 Nov 2016, 5(F1000 Faculty Rev):2651 https://doi.org/10.12688/f1000research.9570.1 


\section{Introduction}

Urolithiasis places a significant economic burden on the healthcare system, especially in industrialized countries where, owing to changes in lifestyle and diet, the incidence of stone disease has steadily increased over the last several decades; unfortunately, it will probably continue to increase for a number of reasons, one of which is global warming ${ }^{1,2}$. Therefore, the costs of medically and surgically treating as well as diagnosing stones will also rise significantly ${ }^{3}$. This highlights the enormous importance of urolithiasis for our healthcare systems. During the last few years, there has been relevant progress in both understanding and managing this disease.

\section{Understanding urolithiasis}

Although first postulated almost 80 years ago $^{4}$, the decisive role of cellular processes and the renal papilla has only recently been generally accepted as the most important step in stone formation.

\section{Managing urolithiasis}

Endourologic techniques were introduced into urolithiasis therapy about 40 years ago. Nevertheless, they have been generally promoted with extending the indications since the beginning of the 21 st century. The main reason for this is improvements in the endoscopic instruments. This allowed higher stone-free rates on one hand and lower complication rates on the other. At this time, all types of stones in any localization may be treated by endoscopic procedures. In consequence, the application of extracorporeal shockwave lithotripsy (ESWL) decreased. Nevertheless, ESWL is still widely used in stone therapy. According to the EAU guidelines ${ }^{5}$, ESWL can be used in nearly all stone locations. Unfavorable factors are shockwave-resistant stones (whewellite, brushite, or cystine), a steep infundibular-pelvic angle, a long lower pole calyx (>10 mm), and a narrow infundibulum $(<5 \mathrm{~mm})$.

\section{Understanding urolithiasis}

Today, urolithiasis is an economic challenge for all healthcare systems ${ }^{6}$. Because of changes in lifestyle, dietary habits, and treatment modalities, its incidence and prevalence rose significantly over the last few decades ${ }^{1}$. One can expect that the frequency of urolithiasis will rise even more (by 7-10\%) owing to global warming, since stone disease is encountered more frequently in hot regions ${ }^{3}$.

A prerequisite for urinary stone formation is the supersaturation of the urine with stone-forming substances like calcium, oxalate, phosphate, and uric acid. Therefore, until now, prevention strategies have been directed towards changes in urine biochemistry ${ }^{7}$. Although the importance of urine biochemistry was questioned by several investigators years ago, it was only recently widely accepted that urine biochemistry cannot explain stone formation exclusively ${ }^{8}$. Many individuals with urinary supersaturation never form stones?.

With the exception of some very rare types of stone disease (e.g. primary hyperoxaluria and cystinuria), for physicochemical reasons crystals cannot grow into stones within the renal tubules, as the transit time is too short (free particle theory). For stone growth, crystals have to be fixed to tubular cells or renal tissue (fixed particle theory ${ }^{10}$ ). A prerequisite for fixation, however, is a lesion of the tissue or cells ${ }^{11}$. Picking up these theories, Robertson recently developed a computer model (NEPHROSIM) that attempts to improve the understanding of reabsorption and secretion processes in the renal tubules and their relevance for the initial processes of calcium oxalate $(\mathrm{CaOx})$ stone formation ${ }^{12}$.

Although these facts have been known for several decades, they came into focus and were generally accepted only recently. Especially for $\mathrm{CaOx}$ urolithiasis, the most common type, stone formation starts with the formation of plaques developing in the basement membrane of the thin loop of Henle ${ }^{13}$. These Randall's plaques consist of apatite and organic material (glycoproteins, glycosaminoglycans, and lipids). Randall's plaques are the nidus for $\mathrm{CaOx}$ stone formation (papillary calcifications). In cases of urine supersaturation with calcium and oxalate, $\mathrm{CaOx}$ crystals adhere and overgrow the apatite plaques. Therefore, it can be stated that there are two prerequisites for $\mathrm{CaOx}$ stone formation: 1 . cellular injury and apatite plaque formation and 2. urine supersaturation with calcium and oxalate.

Why these plaques form is a complex phenomenon and not fully understood. However, there is increasing evidence that renal tubular cell damage and localized inflammation play an important role ${ }^{14}$. Apart from these plaques, Randall ${ }^{15}$ described a second type of papillary lesion (papillary lesion type II), which is an intratubular calcification in the distal part of Bellini's duct. Today, they are called Randall's plugs. They are predominantly found in patients with higher supersaturation of the urine (e.g. primary hyperoxaluria and primary hyperparathyroidism). However, they are also encountered in idiopathic $\mathrm{CaOx}$ stone formers ${ }^{16}$.

\section{Calcium oxalate urolithiasis}

We were interested in how frequently papillary calcifications can be encountered in patients with idiopathic $\mathrm{CaOx}$ urolithiasis ( $\mathrm{iCaOxU}$ ), the most frequent stone type, and whether the assessment of their extent may be used for predicting the risk of recurrence.

We studied 100 patients with $\mathrm{iCaOxU}$ undergoing stone treatment by flexible endourologic instruments ${ }^{17}$. The renal papillae were examined and counted. In addition, the extent of plaques was determined (Figure 1). The so-called calcification index (CI) was calculated: sum of the number of renal papillae multiplied with the grade of calcifications (1-3) multiplied with the number of papillae with calcifications divided by the total number of papillae. Also,

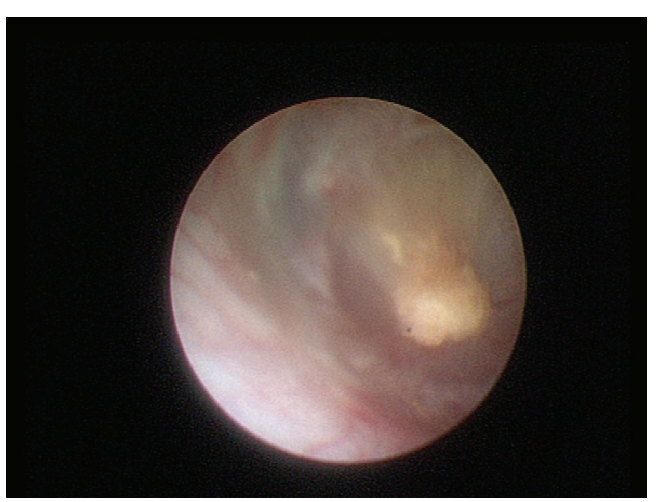

Figure 1. Renal papilla with high-grade calcifications in a patient with idiopathic calcium oxalate urolithiasis. 
a metabolic assessment was done. The CI correlated significantly $(r=0.37 ; p=0.012)$ with the number of stone episodes in the patients' histories.

Concerning the metabolic parameters, only citrate $(r=0.51 ; p=0.002)$ correlated significantly with the number of stone episodes. This is a paradox we can't explain, as citrate is an inhibitor of $\mathrm{CaOx}$ stone formation. These findings highlight the importance of Randall's plaques in the pathogenesis of $\mathrm{iCaOxU}$. Moreover, the assessment of papillary plaques or calcifications by means of endourology and calculating the $\mathrm{CI}$ is a reliable prognostic factor in contrast to conventional metabolic (biochemical) parameters.

The next question to be discussed is how these papillary plaques form. The whole complex is not completely understood so far; however, there is increasing evidence that renal tubular cell damage and localized inflammation play an important role ${ }^{14,18}$. There are two potential ways renal epithelial injury may occur ${ }^{11}$ : firstly, $\mathrm{CaOx}$ and calcium phosphate crystals cause cellular damage, and, secondly, crystals adhere and grow on injured renal epithelial cells. For both potential pathways, oxidative stress and lipid peroxidation are important factors. Some studies showed that parameters of oxidative stress and lipid peroxidation are increased in renal stone formers $^{14,19-22}$.

Experimentally, medications protecting against oxidative stress (e.g. calcium antagonists, $\mathrm{N}$-acetyl-cysteine, and phytopharmaceuticals) could interfere with these mechanisms and lower urinary stone formation $^{1,23-30}$. These observations could open up new options in renal stone prevention and metaphylaxis (secondary prevention) ${ }^{31}$. Standardized preparations like Canephron N containing centaury, lovage, and rosemary exhibit not only anti-oxidative and nephroprotective but also diuretic and anti-inflammatory effects. This unique combination of antiurolithiatic effects is very promising ${ }^{32,33}$. However, this has to be validated by randomized studies. Further research has to concentrate on these aspects of urolithiasis prevention. Stone prevention (metaphylaxis) is a major issue considering the burden it places on healthcare systems. Metaphylaxis is not only medically but also economically effective. An effective metaphylaxis could lower the cost of stone therapy significantly ${ }^{34,35}$.

\section{Uric acid urolithiasis}

Since uric acid (UA) stones are unusually common in our region (Upper Franconia, Germany, 20-25\% of all stone formers) ${ }^{36}$, we investigated the meaning and the importance of papillary plaques in this type of urolithiasis. So far, there are only very limited data existing in the literature. Viers et al. ${ }^{37}$ published a series of 23 patients with stones containing UA. However, only four had pure UA stones. The vast majority was mixed with $\mathrm{CaOx}$. Until now, we have examined 30 patients suffering from pure UA stones. The study design was as outlined above for $\mathrm{iCaOxU}$. Our preliminary data showed that - contrary to $\mathrm{iCaOx}(7.7 \pm 7.9)$ - the CI was significantly lower in UA stones $(5.04 \pm 4.39)$. Nevertheless, the number of stone episodes or recurrence rate was higher in UA stones. There was no correlation between the CI and recurrence rate. Regarding the biochemical metabolic parameters, blood calcium correlated positively and urine $\mathrm{pH}$ and volume negatively with the recurrence rate.
UA plaques of the renal papillae obviously are not of such importance in the pathogenesis of stone formation as they are in $\mathrm{iCaOxU}$. According to our preliminary results, they do not correlate with the number of recurrences. Therefore, they may not be used to predict the risk of recurrence. However, these first results should be confirmed in larger numbers of UA stone patients. Our observations again demonstrate that urolithiasis is a very complex phenomenon and that there are different pathways in stone formation for the different types of stones.

\section{Managing urolithiasis}

Since the beginning of the 21 st century, the general acceptance and the dissemination of endoscopic therapy modalities rose dramatically ${ }^{38-41}$. The word "endourology" goes back to Arthur Smith. It means a "closed, controlled manipulation in the genitourinary tract". In the field of renal and ureteral stones, endourologic treatment modalities include ureterorenoscopy (URS), laparoscopic ureterolithotomy, percutaneous nephrolithotomy (PCNL), and laparoscopic pyelolithotomy. The main reason for this dramatic rise in the use of these procedures is technical improvements in the instruments. These newer instruments allow for higher success rates and reduced morbidity.

Nevertheless, ESWL is still widely used for treating both ureteral and renal stones. The number of ESWL treatments, however, has decreased during the last few decades. In contrast, endourologic procedures were used more frequently ${ }^{39,42-44}$. At this time, urinary stones of all types and localizations can be treated by endoscopic modalities with similar stone-free rates and morbidity in comparison to ESWL.

\section{Management of renal stones}

ESWL is indicated preferentially in renal stones up to $2 \mathrm{~cm}$ in diameter when located in the renal pelvis and upper and middle calyces. In these cases, stone-free rates from $80-100 \%$ can be achieved sometimes; however, it requires multiple sessions. Complication rates range from $0-20 \%{ }^{5}$.

Lower pole stones do not respond so well, especially in the case of unfavorable factors for ESWL (shockwave-resistant stones [whewellite, brushite, and cystine], steep infundibular-pelvic angle, long lower pole $[>10 \mathrm{~mm}]$, and narrow infundibulum $[<5 \mathrm{~mm}]$ ). Those stones should be treated preferentially by endourologic modalities $^{5,45,46}$.

Various forms of PCNL (conventional, mini, ultra-mini, and micro PCNL) are available for treating all renal stones (Figure $2 \mathrm{a}$ and $2 \mathrm{~b}$ ). The range of the diameters of these instruments varies between 5 (micro PCNL) and $34 \mathrm{~F}$ (large standard PCNL) ${ }^{16,47}$. Although there is some evidence that smaller instruments cause less trauma, this has not really been proven ${ }^{5}$. On the other hand, operating time increases with decreasing diameter of the instrument. Further studies are required to establish the definitive role of miniaturized instruments. In the meantime, it seems wise to adapt the diameter of the instruments to the size of the stone.

The overall complication rates for PCNL range from $0-30 \%$. Concerning stone-free rates, the diameter, composition, and localization 
a

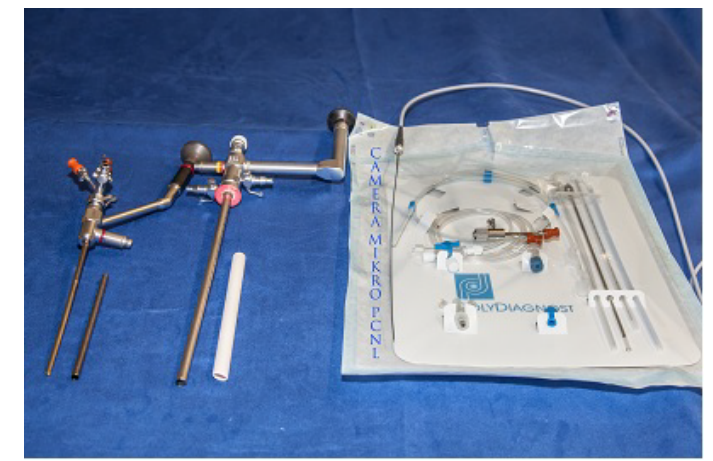

b

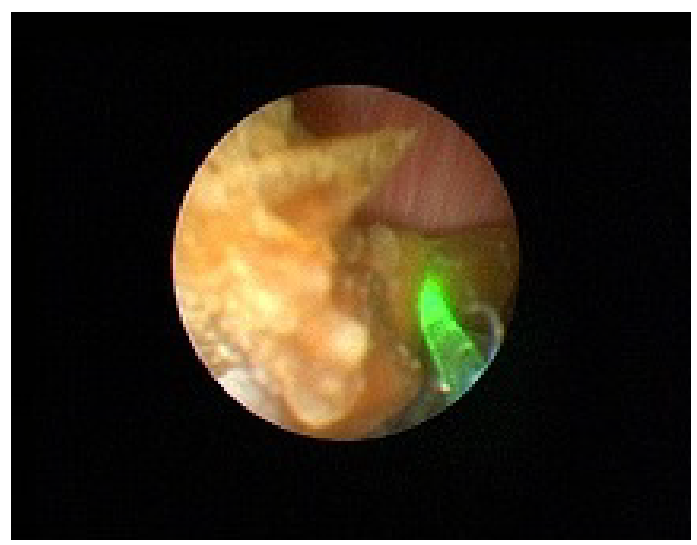

Figure 2. a. Mini, standard, and micro percutaneous nephrolithotomy (PCNL) instruments. b. Stone disintegration using a holmium laser during mini percutaneous nephrolithotomy (PCNL).

of the stones have to be considered. Stone-free rates range from $100 \%$ in small to about $60 \%$ in complex (e.g. staghorn) stones ${ }^{5}$.

Retrograde intrarenal surgery (RIRS) using flexible ureterorenoscopes can be used to manage especially small stones. According to size, composition, and localization of the stone, stone-free rates vary from $65-100 \%$. Complications occur in $0-20 \%^{5,45,46,48,49}$.

In a select few cases, laparoscopic stone removal is another option (treatment failure of other modalities and concomitant anomalies such as pyelo-ureteral junction obstruction and obstructing cysts). Open surgery is extremely rare today ${ }^{5,45,46}$.

\section{Management of ureteral stones}

ESWL may be used for all stones in the ureter. The stone-free rates range from $85-100 \%$. Complication rates range from 0-20\%. However, large distal stones should be treated preferentially by endourologic therapy, as the stone-free rates are higher ${ }^{5,45,46}$.

For endoscopic therapy of ureteral stones, different types of ureteroscopes (semirigid and flexible) are available (Figure $3 \mathrm{a}$ and $3 \mathrm{~b})$. To reduce the trauma, small instruments with tip diameters $<8 \mathrm{~F}$ should be used. The stone-free rates range from $85-100 \%$ and the complication rates between 0 and $20 \% \%^{5,45,46}$. In a

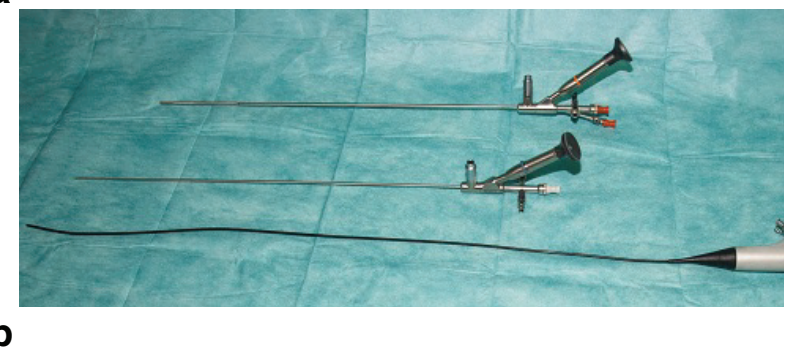

b

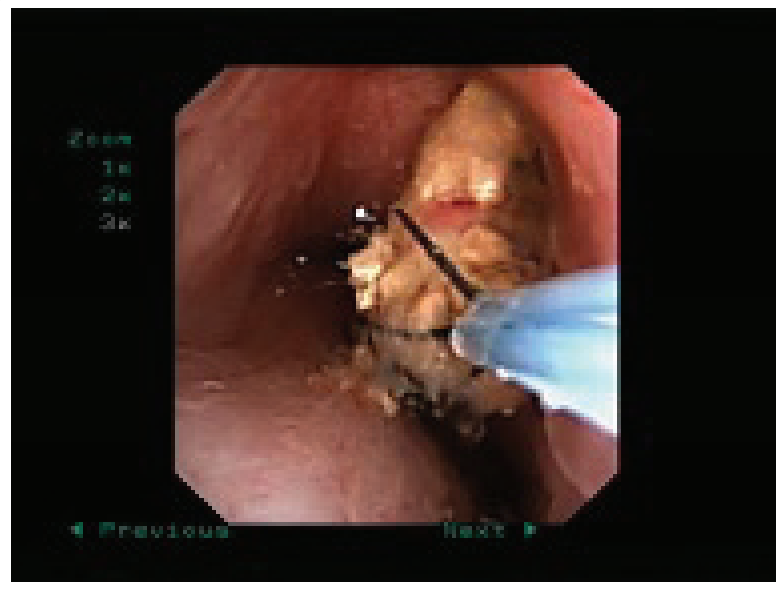

Figure 3. a. Semirigid and flexible instruments for ureterorenoscopy. b. Stone extraction from a renal calyx using a flexible ureterorenoscope and a tipless basket.

unusual situations, laparoscopic surgery may be indicated (treatment failures of endourologic modalities and extremely large stones). Open surgery is almost never required today $y^{5,45,46}$.

\section{Stone fragmentation}

In many situations, in the kidney and the ureter as well, stones are too large to be extracted completely. Therefore, they have to be disintegrated (fragmented). For this purpose, a number of approaches are available, such as laser, ultrasound, and pneumatic. The gold standard is the holmium laser, as it is highly effective and can be used with flexible devices. When treating larger stones with semirigid and rigid instruments (URS and PCNL), pneumatic and ultrasound lithotripters can be used, as they reduce operating time ${ }^{50}$.

In summary, endourology has improved stone therapy significantly over the last several years. Morbidity decreased and success (stone-free) rates increased. Therefore, the indications for ESWL narrowed. However, when used in the broad field and looked at carefully, the re-intervention rate for residual fragments after URS was about $40 \%$. This is similar to that of ESWL ${ }^{51,52}$. Potentially, these differences in the success rates of URS are because of different techniques (e.g. using access sheaths and flexible instruments or not, or removing the stone fragments using baskets or dusting the stone). In the end, it could be that URS may not be quite as effective as we like to believe ${ }^{53}$. ESWL still has its place in stone therapy. There is not one single treatment modality that is equally effective for all situations. It is important to observe the differential indications as outlined above. 


\section{Future outlook}

Some questions remain to be answered in the future. Will further miniaturization of the instruments really be less traumatic and give the same results? Could stone fragmentation be improved (e.g. by more effective lasers)? Another issue is economy: flexible ureterorenoscopes, while being versatile and less traumatic, are expensive and not very durable. Their further dissemination is dependent on economic factors. Will single-use instruments help ${ }^{54}$ ? Recently, robotic support has been introduced to endourologic stone therapy. However, so far, there are limited advantages ${ }^{55}$.

\section{Abbreviations}

$\mathrm{CaOx}$, calcium oxalate; $\mathrm{CI}$, calcification index; ESWL, extracorporeal shockwave lithotripsy; $\mathrm{iCaOxU}$, idiopathic calcium oxalate urolithiasis; PCNL, percutaneous nephrolithotomy;
RIRS, retrograde intrarenal surgery (RIRS); UA, uric acid; URS, ureterorenoscopy.

\section{Competing interests}

The author is a consultant of Bionorica SE, Neumarkt/Oberpfalz, Germany.

\section{Grant information}

The author(s) declared that no grants were involved in supporting this work.

\section{Acknowledgements}

I thank Mr Andreas Giese, Head Nurse of our endourology service, for taking the photographs.
1. Hesse A, Brändle E, Wilbert D, et al:: Study on the prevalence and incidence of urolithiasis in Germany comparing the years 1979 vs. 2000. Eur Urol. 2003; 44(6): 709-13.

PubMed Abstract | Publisher Full Text

2. Strohmaier WL: Economics of stone disease/treatment. Arab J Urol. 2012; 10(3): 273-8.

PubMed Abstract | Publisher Full Text | Free Full Text

3. F Brikowski TH, Lotan Y, Pearle MS: Climate-related increase in the prevalence of urolithiasis in the United States. Proc Natl Acad Sci U S A. 2008 105(28): 9841-6.

PubMed Abstract | Publisher Full Text | Free Full Text | F1000 Recommendation

4. Randall A: An hypothesis for the origin of renal calculus. N Engl J Med. 1936; 214: 234-242. Publisher Full Text

5. Türk C, Petř́ik A, Sarica K, et al.: EAU Guidelines on Interventional Treatment for Urolithiasis. Eur Urol. 2016; 69(3): 475-82.

PubMed Abstract | Publisher Full Text

6. Lotan Y: Economics and cost of care of stone disease. Adv Chronic Kidney Dis. 2009; 16(1): 5-10.

PubMed Abstract | Publisher Full Text

7. Türk C, Petř́k A, Sarica K, et al.: EAU Guidelines on Diagnosis and Conservative Management of Urolithiasis. Eur Urol. 2016; 69(3): 468-74. PubMed Abstract | Publisher Full Text

8. F Coe FL, Evan AP, Worcester EM, et al:: Three pathways for human kidney stone formation. Urol Res. 2010; 38(3): 147-60.

PubMed Abstract | Publisher Full Text | Free Full Text | F1000 Recommendation

9. Robertson WG, Peacock M, Marshall RW, et al:: Saturation-inhibition index as a measure of the risk of calcium oxalate stone formation in the urinary tract. $N$ Engl J Med. 1976; 294(5): 249-52. PubMed Abstract | Publisher Full Text

10. Finlayson $B$, Reid $F$ : The expectation of free and fixed particles in urinary stone disease. Invest Urol. 1978; 15(6): 442-8. PubMed Abstract

11. Strohmaier WL, Bichler KH: Cellular aspects of stone formation. Bichler $\mathrm{KH}$ Strohmaier WL, Wilbert DM, Mattauch W and (eds.). Urolithiasis. Tübingen, Attempto. $1995 ; 1-12$

12. F Robertson WG: Potential role of fluctuations in the composition of renal tubular fluid through the nephron in the initiation of Randall's plugs and calcium oxalate crystalluria in a computer model of renal function. Urolithiasis. 2015; 43(Suppl 1): 93-107.

PubMed Abstract | Publisher Full Text | F1000 Recommendation

13. Evan A, Lingeman J, Coe FL, et al.: Randall's plaque: pathogenesis and role in calcium oxalate nephrolithiasis. Kidney Int. 2006; 69(8): 1313-8. PubMed Abstract | Publisher Full Text

14. F Khan SR: Reactive oxygen species as the molecular modulators of calcium oxalate kidney stone formation: evidence from clinical and experimental investigations. J Urol. 2013; 189(3): 803-11. PubMed Abstract | Publisher Full Text | F1000 Recommendation

15. Randall A: Papillary pathology as a precursor of primary renal calculus. J Urol. 1940; 44: 580-589.

16. Linnes MP, Krambeck AE, Cornell L, et al.: Phenotypic characterization of kidney stone formers by endoscopic and histological quantification of intrarenal calcification. Kidney Int. 2013; 84(4): 818-25.

PubMed Abstract | Publisher Full Text | Free Full Text

17. Strohmaier WL, Hörmann M, Schubert G: Papillary calcifications: a new prognostic factor in idiopathic calcium oxalate urolithiasis. Urolithiasis. 2013; 41(6): 475-9.

PubMed Abstract | Publisher Full Text

18. Khan SR: Crystal/cell interaction and nephrolithiasis. Arch Ital Urol Androl. 2011; 83(1): 1-5.

PubMed Abstract

19. Green W, Ratan H: Molecular mechanisms of urolithiasis. Urology. 2013; 81(4): $701-4$

PubMed Abstract | Publisher Full Text

20. Huang HS, Ma MC, Chen CF, et al.: Changes in nitric oxide production in the rat kidney due to CaOx nephrolithiasis. Neurourol Urodyn. 2006; 25(3): 252-8. PubMed Abstract | Publisher Full Text

21. F Ma MC, Chen YS, Huang HS: Erythrocyte oxidative stress in patients with calcium oxalate stones correlates with stone size and renal tubular damage. Urology. 2014; 83(2): 510.e9-17.

PubMed Abstract | Publisher Full Text | F1000 Recommendation

22. Schwille PO, Schmiedl A, Manoharan M, et al.: Idiopathic Recurrent Calcium Urolithiasis (IRCU): pathophysiology evaluated in light of oxidative metabolism, without and with variation of several biomarkers in fasting urine and plasma--a comparison of stone-free and -bearing male patients, emphasizing mineral, acid-base, blood pressure and protein status. Eur J Med Res. 2011; 16(8): 349-66.

PubMed Abstract | Publisher Full Text | Free Full Text

23. Bichler $\mathrm{KH}$, Strohmaier WL, Schanz $\mathrm{F}$, et al:: [Effect of calcium antagonists (nifedipine) on nephrocalcinosis and calcium excretion in the rat]. Urol Int. 1985; 40(1): 13-21.

PubMed Abstract

24. Buck AC, Davies RL, Harrison T: The protective role of eicosapentaenoic acid [EPA] in the pathogenesis of nephrolithiasis. J Urol. 1991; 146(1): 188-94. PubMed Abstract

25. Davalos $\mathrm{M}$, Konno $\mathrm{S}$, Eshghi $\mathrm{M}$, et al:: Oxidative renal cell injury induced by calcium oxalate crystal and renoprotection with antioxidants: a possible role of oxidative stress in nephrolithiasis. J Endourol. 2010; 24(3): 339-45. PubMed Abstract | Publisher Full Text

26. Strohmaier WL, Seeger D, Osswald $\mathrm{H}$, et al.: Renal insufficiency induced by parathyroid hormone: influence of the calcium antagonist Gö 6070. Eur Urol. 1992; 21(4): 323-7. PubMed Abstract 
27. Strohmaier WL, Seeger RD, Osswald $\mathrm{H}$, et al:: Reduction of vitamin $\mathbf{D}$ induced stone formation by calcium. Urol Res. 1994; 22(5): 301-3. PubMed Abstract | Publisher Full Text

28. Strohmaier WL, Witte B, Nelde HJ: Influence of nifedipine on stone formation and renal function in cholesterol-induced nephrolithiasis in rats. Urol Int. 1994 52(2): 87-92.

PubMed Abstract | Publisher Full Text

29. Vidya L, Lenin M, Varalakshmi P: Evaluation of the effect of triterpenes on urinary risk factors of stone formation in pyridoxine deficient hyperoxaluric rats. Phytother Res. 2002; 16(6): 514-8. PubMed Abstract | Publisher Full Text

30. Vidya L, Varalakshmi P: Control of urinary risk factors of stones by betulin and lupeol in experimental hyperoxaluria. Fitoterapia. 2000; 71(5): 535-43. PubMed Abstract | Publisher Full Text

31. Monti E, Trinchieri A, Magri V et al: Herbal medicines for urinary ston treatment. A systematic review. Arch Ital Urol Androl. 2016; 88(1): 38-46. PubMed Abstract | Publisher Full Text

32. Ceban E: Efficacy of a fixed combination of Centaurii herba, Levistici radix and Rosmarini folium in urinary lithiasis. Z Phytother. 2012; 33(1): 19-23. Publisher Full Text

33. Naber KG: Efficacy and safety of the phytotherapeutic drug Canephron ${ }^{\circledast} \mathrm{N}$ in prevention and treatment of urogenital and gestational disease: review of clinical experience in Eastern Europe and Central Asia. Res Rep Urol. 2013; 5: 39-46. PubMed Abstract | Publisher Full Text | Free Full Text

34. Lotan $\mathrm{Y}$, Pearle MS: Cost-effectiveness of primary prevention strategies for nephrolithiasis. J Urol. 2011; 186(2): 550-5. PubMed Abstract | Publisher Full Text

35. Strohmaier WL: [Economic aspects of evidence-based metaphylaxis]. Urologe $A$. 2006; 45(11): 1406-9.

PubMed Abstract | Publisher Full Tex

36. Strohmaier WL, Weigl A: Stone composition in Upper Franconia - unusually high percentage of uric acid lithiasis. Jungers, $\mathrm{P}$ and Daudon, M. Renal Stone Disease. Amsterdam, New York, Elsevier Science 1997; 10-11.

37. F Viers BR, Lieske JC, Vrtiska TJ, et al.: Endoscopic and histologic findings in a cohort of uric acid and calcium oxalate stone formers. Urology. 2015; 85(4): $771-6$.

PubMed Abstract | Publisher Full Text | Free Full Text | F1000 Recommendation

38. Ghani KR, Andonian S, Bultitude M, et al:: Percutaneous Nephrolithotomy: Update, Trends, and Future Directions. Eur Urol. 2016; 70(2): 382-96. PubMed Abstract | Publisher Full Text

39. Ghani KR, Sammon JD, Karakiewicz PI, et al.: Trends in surgery for uppe urinary tract calculi in the USA using the Nationwide Inpatient Sample: 1999-2009. BJU Int. 2013; 112(2): 224-30. PubMed Abstract | Publisher Full Text

40. Giusti G, Proietti S, Peschechera R, et al:: Sky is no limit for ureteroscopy: extending the indications and special circumstances. World J Urol. 2015; 33(2): 257-73. PubMed Abstract | Publisher Full Text

41. Marchini GS, Mello MF, Levy R, et al: Contemporary Trends of Inpatient Surgical Management of Stone Disease: National Analysis in an Economic Growth Scenario. J Endourol. 2015; 29(8): 956-62.

PubMed Abstract | Publisher Full Text

42. Garcia-Galisteo E, Sánchez-Martinez N, Molina-Diaz P, et al.: Invasive treatment trends in urinary calculi in a third level hospital. Actas Urol Esp. 2015; 39(1): 32-7. PubMed Abstract | Publisher Full Text

43. Oberlin DT, Flum AS, Bachrach L, et al:: Contemporary surgical trends in the management of upper tract calculi. $J$ Urol. 2015; 193(3): 880-4. PubMed Abstract | Publisher Full Text

44. Seklehner S, Laudano MA, Del Pizzo J, et al.: Renal calculi: trends in the utilization of shockwave lithotripsy and ureteroscopy. Can J Urol. 2015; 22(1): 7627-34. PubMed Abstract

45. F Assimos D, Krambeck A, Miller NL, et al:: Surgical Management of Stones: American Urological Association/Endourological Society Guideline, PART I. J Urol. 2016; 196(4): 1153-60.

PubMed Abstract | Publisher Full Text | F1000 Recommendation

46. Assimos D, Krambeck A, Miller NL, et al.: Surgical Management of Stones: American Urological Association/Endourological Society Guideline, PART II. J Urol. 2016; 196(4): 1161-9. PubMed Abstract | Publisher Full Text

47. $\mathrm{F}$ Kamal W, Kallidonis $\mathrm{P}$, Kyriazis I, et al:: Minituriazed percutaneous nephrolithotomy: what does it mean? Urolithiasis. 2016; 44(3): 195-201.

PubMed Abstract | Publisher Full Text | F1000 Recommendation

48. $\mathrm{F}$ Berardinelli F, Proietti S, Cindolo L, et al:: A prospective multicenter European study on flexible ureterorenoscopy for the management of rena stone. Int Braz J Urol. 2016; 42(3): 479-86.

PubMed Abstract | Publisher Full Text | Free Full Text | F1000 Recommendation

49. Schoenthaler M, Wilhelm K, Katzenwadel A, et al.: Retrograde intrarenal surgery in treatment of nephrolithiasis: is a $100 \%$ stone-free rate achievable? $J$ Endourol. 2012; 26(5): 489-93.

PubMed Abstract | Publisher Full Text

50. Garg S, Mandal AK, Singh SK, et al.: Ureteroscopic laser lithotripsy versus ballistic lithotripsy for treatment of ureteric stones: a prospective comparative study. Urol Int. 2009; 82(3): 341-5.

PubMed Abstract | Publisher Full Text

51. F Chew BH, Brotherhood HL, Sur RL, et al:: Natural History, Complications and Re-Intervention Rates of Asymptomatic Residual Stone Fragments after Ureteroscopy: a Report from the EDGE Research Consortium. J Urol. 2016; 195(4P1): 982-6.

PubMed Abstract | Publisher Full Text | F1000 Recommendation

52. $\mathrm{F}$ Rippel CA, Nikkel L, Lin YK, et al:: Residual fragments following ureteroscopic lithotripsy: incidence and predictors on postoperative computerized tomography. J Urol. 2012; 188(6): 2246-51. PubMed Abstract | Publisher Full Text | F1000 Recommendation

53. Pearle MS: Is Ureteroscopy as Good as We Think? J Urol. 2016; 195(4P1): 823-4 PubMed Abstract | Publisher Full Text

54. F Proietti S, Dragos L, Molina W, et al:: Comparison of New Single-Use Digital Flexible Ureteroscope Versus Nondisposable Fiber Optic and Digita Ureteroscope in a Cadaveric Model. J Endourol. 2016; 30(6): 655-9. PubMed Abstract | Publisher Full Text | Free Full Text | F1000 Recommendation

55. F Saglam R, Muslumanoglu AY, Tokatli Z, et al.: A new robot for flexible ureteroscopy: development and early clinical results (IDEAL stage 1-2b) Eur Urol. 2014; 66(6): 1092-100.

PubMed Abstract | Publisher Full Text | F1000 Recommendation 


\section{Open Peer Review}

\section{Current Peer Review Status:}

\section{Editorial Note on the Review Process}

Faculty Reviews are review articles written by the prestigious Members of Faculty Opinions. The articles are commissioned and peer reviewed before publication to ensure that the final, published version is comprehensive and accessible. The reviewers who approved the final version are listed with their names and affiliations.

\section{The reviewers who approved this article are:}

\section{Version 1}

\section{Hans-Goran Tiselius}

Karolinska Institutet, Department of Clinical Science Intervention and Technology, Stockholm, Sweden Competing Interests: No competing interests were disclosed.

\section{Amy Krambeck} Indiana University, Indianapolis, IN, USA

Competing Interests: No competing interests were disclosed.

\section{Chanderdeep Tandon}

Amity Institute of Biotechnology, Amity University, Noida, India

Competing Interests: No competing interests were disclosed.

The benefits of publishing with F1000Research:

- Your article is published within days, with no editorial bias

- You can publish traditional articles, null/negative results, case reports, data notes and more

- The peer review process is transparent and collaborative

- Your article is indexed in PubMed after passing peer review

- Dedicated customer support at every stage

For pre-submission enquiries, contact research@f1000.com 